\title{
Compartmental Localization of a Metabotropic Glutamate Receptor (mGluR7): Two Different Active Sites at a Retinal Synapse
}

\author{
Johann Helmut Brandstätter, ${ }^{1}$ Peter Koulen, ${ }^{1}$ Rainer Kuhn, ${ }^{2}$ Herman van der Putten, ${ }^{2}$ and Heinz Wässle ${ }^{1}$ \\ ${ }^{1}$ Max-Planck-Institut für Hirnforschung, Abteilung für Neuroanatomie, D-60528 Frankfurt am Main, Germany, and ${ }^{2}$ Central \\ Nervous System Research, CIBA, CH-4002 Basel, Switzerland
}

\begin{abstract}
The distribution of the metabotropic glutamate receptor 7 (mGluR7) was studied in the rat retina using a specific antiserum. Punctate immunofluorescence that corresponded to synaptic localization was present exclusively in the inner plexiform layer. Double-labeling experiments suggested that mGluR7 is expressed at the synaptic terminals of certain cone bipolar cells. Electron microscopy showed that mGluR7 was present both presynaptically, as an autoreceptor in cone bipolar cell ribbon synapses, and postsynaptically in amacrine cells. There are usually two postsynaptic processes at a bipolar cell
\end{abstract}

ribbon synapse; however, the presynaptic aggregation of mGluR7 was restricted to one half of the active zone and therefore was opposed to only one of the postsynaptic processes. This selective localization of mGluR7 could differentially regulate the glutamate release from the ribbon synapse, thus leading to a differential activation of the postsynaptic neurons.

Key words: cone bipolar cells; ribbon synapse; mGluR7; autoreceptor; presynaptic; postsynaptic; rat retina; retinal development
Glutamate plays an important role in retinal circuitry. Photoreceptors, bipolar cells, and ganglion cells release glutamate to mediate the direct transfer of visual information, whereas inhibitory interactions from horizontal and amacrine cells generally depend on GABA or glycine (Brecha, 1983; Massey and Redburn, 1987; Massey, 1990). Heterogeneity at the postsynaptic site, e.g., differential expression of neurotransmitter receptors, is the major source of complexity in modulating the flow of information from photoreceptors to ganglion cells (Grünert and Wässle, 1993; Hamassaki-Britto et al., 1993; Keyser et al., 1993; Brandstätter et al., 1994; Hartveit et al., 1994; Nomura et al., 1994; SassoèPognetto et al., 1994; Greferath et al., 1995; Peng et al., 1995).

The effects of glutamate are mediated by two classes of receptors: ionotropic and metabotropic. Ionotropic glutamate receptors account for the majority of fast excitatory synaptic transmission in the CNS (for reviews, see Monaghan et al., 1989; Seeburg, 1993; Hollmann and Heinemann, 1994), whereas metabotropic glutamate receptors (mGluRs) influence various intracellular second messenger systems via interaction with membrane-bound G-proteins (Sladeczek et al., 1985; Sugiyama et al., 1987; for review, see Pin and Duvoisin, 1995). Eight mGluRs have been cloned and characterized so far; these receptors can be subdivided into three groups based on sequence similarities, pharmacology, and preferentially coupled second messengers in heterologous expression systems (for reviews, see Hollmann and Heinemann, 1994; Nakanishi, 1994; Pin and Duvoisin, 1995).

Group III receptors, mGluRs 4, 6, 7, and 8, react most strongly to L-2-amino-4-phosphonobutyrate (L-AP4) and L-serine- $O$ -

\footnotetext{
Received March 25, 1996; revised May 2, 1996; accepted May 7, 1996.

This study was supported by a grant from the Deutsche Forschungsgemeinschaft (SFB 269/B4). We thank W. Hofer, A. Leihkauf, and G.-S. Nam for excellent technical assistance, and Drs. D. Calkins and J. Kirsch for critically reading and improving this manuscript.

Correspondence should be addressed to Johann H. Brandstätter, Max-PlanckInstitut für Hirnforschung, Abteilung für Neuroanatomie, Deutschordenstrasse 46, D-60528 Frankfurt am Main, Germany.

Copyright (C) 1996 Society for Neuroscience $0270-6474 / 96 / 164749-08 \$ 05.00 / 0$
}

phosphate (L-SOP) and act via inhibition of adenylyl cyclase, consequently decreasing the levels of cAMP (Tanabe et al., 1992; Nakajima et al., 1993; Tanabe et al., 1993; Okamoto et al., 1994; Saugstad et al., 1994; Duvoisin et al., 1995). In the retina, visual information is segregated into parallel pathways, for example, ON and OFF pathways (for reviews, see Wässle and Boycott, 1991; Schiller, 1995). The L-AP4-sensitive mGluR6 is localized exclusively to the postsynaptic, dendritic part of ON-type bipolar cells in the adult rat retina (Nomura et al., 1994). When the mGluR6 gene was disrupted, the $\mathrm{ON}$ responses to light were abolished completely (Masu et al., 1995). MGluR6 is therefore essential for synaptic transmission from the photoreceptor cells to the bipolar cells in the ON pathway of the retina. The presence in retinal bipolar cells of another member of the group III mGluRs, mGluR7, was shown with in situ hybridization (Hartveit et al., 1995). This finding of mGluR7 mRNA in retinal bipolar cells raises a major question: does mGluR7, like mGluR6, play a role in glutamatergic synaptic transmission from photoreceptors to bipolar cells, or is mGluR7 used elsewhere in the bipolar cell function?

We have undertaken a detailed examination of the cellular and subcellular localization of mGluR7 in the rat retina using a receptor-specific antipeptide antiserum raised against mGluR7. We report that mGluR7 is not involved in synaptic processing in the outer plexiform layer (OPL) but is involved in the inner plexiform layer (IPL), and that mGluR7 is localized pre- and postsynaptically at certain cone bipolar cell ribbon synapses. Selective presynaptic localization of mGluR7 creates a possible mechanism for differential release of glutamate from bipolar cell ribbon synapses.

\section{MATERIALS AND METHODS}

Generation of the antiserum against mGluR7

A peptide corresponding to the C-terminal amino acid sequence of mGluR7, PAAKKKYVSYNNLVI (position 901-915; Okamoto et al., 1994), was synthesized and coupled to keyhole limpet hemocyanin. Polyclonal antisera were raised in New Zealand white rabbits according to 
standard techniques (Harlow and Lane, 1988). Antibodies were precipitated with ammonium sulfate and purified by immunoaffinity chromatography with peptide-coupled Affigel 10/15 (Bio-Rad, Richmond, CA).

\section{Western blot of retina membranes}

Albino rats were anesthetized deeply and decapitated. The retinas were dissected, homogenized in lysis buffer containing 4 mM HEPES, $220 \mathrm{~mm}$ $\mathrm{D}(+)$-mannose, $70 \mathrm{~mm}$ sucrose, $1 \mathrm{mg} / \mathrm{ml}$ benzamidine hydrochloride, 0.5 $\mathrm{mg} / \mathrm{ml}$ aprotinin (Merck, Darmstadt, Germany), and $0.25 \mathrm{mg} / \mathrm{ml}$ benzethonium chloride (Sigma, Deisenhofen, Germany) at $\mathrm{pH} 7.5$, and centrifuged at $4^{\circ} \mathrm{C}$ for $3 \mathrm{~min}$ at $1000 \times \mathrm{g}$. Subsequently the supernatant was centrifuged for $15 \mathrm{~min}$ at $15000 \times \mathrm{g}$. The pellet was resuspended in lysis buffer to obtain a crude retinal membrane protein fraction. After denaturation with SDS and 2-mercaptoethanol, crude retinal membrane proteins $(80 \mu \mathrm{g} / \mathrm{lane})$ and biotinylated SDS molecular weight markers were electrophoresed on $7.5 \%$ SDS-polyacrylamide gels. Proteins were transferred onto cationized nylon membranes by standard Western blotting technique. After incubation with blocking buffer [5\% (v/v) normal goat serum (NGS), $0.05 \%$ (w/v) Tween 20 in PBS (0.01 M, pH 7.4)] for $1 \mathrm{hr}$ at room temperature, blots were incubated with primary $(0.1 \mu \mathrm{g} / \mathrm{ml})$ and secondary antibodies for $1 \mathrm{hr}$ each in blocking buffer. Binding of the antiserum against mGluR7 to polypeptides was detected by goat antirabbit IgG antibodies coupled to alkaline phosphatase (diluted 1:100; Dianova, Hamburg, Germany) using 5-bromo-4-chloro-3-indolyl phosphate and nitro-blue tetrazolium (Boehringer Mannheim Biochemica, Mannheim, Germany) as substrates.

\section{Generation of mGluR7 knock-out mice}

MGluR7 knock-out mice were generated from E14 ES cells, in which a single mGluR7 allele was initially disrupted using a conventional replacement vector (Stief at al., 1994). The gene-targeting event deleted part of the mGluR7 gene $5^{\prime}$-untranslated sequences, the codons for the first 164 amino acids of the mGluR7 protein, and part of the first intron. As a result, mGluR7-/- mice completely lack mGluR7 mRNA and protein as assessed by Northern blot, RT-PCR, Western blot, and immunocytochemical analysis (H. van der Putten, unpublished observations).

\section{Immunocytochemistry}

Tissue preparation. Retinas of adult albino rats, 6- to 8-weeks-old, and of different postnatal stages, 1- to 30-d-old, were investigated. For the developmental studies, only retinas from the same litter mates and only retinal pieces with the same eccentricity were compared. The rats were anesthetized deeply with halothane and decapitated. For light microscopy, the eyes were opened along the ora serrata, and the eyecups were immersion-fixed for 15,30 , or $45 \mathrm{~min}$ in $4 \%(\mathrm{w} / \mathrm{v})$ paraformaldehyde in phosphate buffer (PB; $0.1 \mathrm{M}, \mathrm{pH}$ 7.4). The vitreous body was removed, and the retinas were dissected free. The retinas were cryoprotected in $10 \%(\mathrm{w} / \mathrm{v}), 20 \%(\mathrm{w} / \mathrm{v})$ sucrose in PB for $1 \mathrm{hr}$ each and in $30 \%(\mathrm{w} / \mathrm{v})$ sucrose in PB overnight at $4^{\circ} \mathrm{C}$. Pieces of retinas that had been fixed for different periods of time were mounted in freezing medium (ReichertJung, Bensheim, Germany), sectioned vertically at $12 \mu \mathrm{m}$ thickness on a cryostat, and collected on gelatin-coated slides.

For electron microscopy, the eyecups were fixed in $4 \%(\mathrm{w} / \mathrm{v})$ paraformaldehyde and $0.05 \%$ (v/v) glutaraldehyde in PB for $10 \mathrm{~min}$, followed by an additional $40 \mathrm{~min}$ in $4 \%(\mathrm{w} / \mathrm{v})$ paraformaldehyde in PB. After dissecting out and cryoprotecting the retinas, they were frozen and thawed repeatedly to enhance the penetration of the antibodies. After the retinas were washed in PBS (0.01 M, pH 7.4), small pieces of retina were embedded in agar, and vertical sections $(60 \mu \mathrm{m}$ thick) were cut with a vibratome for preembedding electron microscopic immunocytochemistry.

Light microscopic immunohistochemistry. To characterize the cellular distribution of mGluR7, antibodies known to stain distinct populations of retinal neurons were combined in double-labeling experiments with the specific anti-peptide antiserum against mGluR7. The antibodies used were pAb against mGluR7 ( $1 \mu \mathrm{g} / \mathrm{ml}), \mathrm{mAb}$ MC-3A against PKC $\alpha$ (1:100; Seikagaku, Tokyo, Japan), and mAb 13D3.A10 against calbindin D-28K (1:1000; Pinol et al., 1990; kindly provided by W. Hunziker, Hoffmann-La Roche AG, Basel, Switzerland). Immunocytochemical labeling was carried out using the indirect fluorescence method. The binding sites of the primary antibodies were revealed by secondary antibodies: goat antimouse, goat anti-rat, or goat anti-rabbit IgG coupled to either carboxymethylindocyanine ( $\mathrm{Cy} 3$, red fluorescence; Dianova, Hamburg, Germany) diluted 1:1000 or fluorescein-isothiocyanate (FITC, green fluorescence; Sigma-Aldrich, Deisenhofen, Germany) diluted 1:100.

Preembedding immunoelectron microscopy. The vibratome sections were collected in cold PBS, immersed for blocking for $2 \mathrm{hr}$ in $10 \%$ NGS $(\mathrm{v} / \mathrm{v})$ in PBS, and then incubated in the primary antiserum against mGluR7. It was diluted $(1: 190)$ in the same medium used for light microscopy, but without Triton X-100, for 4 days at $4 \mathrm{C}$. Thereafter, the sections were rinsed in PBS several times and incubated for $2 \mathrm{hr}$ at room temperature in biotinylated goat anti-rabbit IgG (1:100; Amersham, Braunschweig, Germany). After the sections were rinsed again in PBS, they were transferred to a solution containing the extravidin-peroxidase complex (1:100; Sigma-Aldrich) for $2 \mathrm{hr}$ at room temperature. After washes in PBS and in $0.05 \mathrm{M}$ Tris- $\mathrm{HCl}, \mathrm{pH} 7.6$, the sections were preincubated for $10 \mathrm{~min}$ in 3,3'-diaminobenzidine $(\mathrm{DAB})[0.05 \%(\mathrm{v} / \mathrm{v})$ in $0.05 \mathrm{M}$ Tris- $\mathrm{HCl}, \mathrm{pH} 7.6]$ and then reacted in $0.05 \%(\mathrm{v} / \mathrm{v}) \mathrm{DAB}$ with $0.01 \%(\mathrm{v} / \mathrm{v}) \mathrm{H}_{2} \mathrm{O}_{2}$. The staining reaction was stopped by rinsing the sections in Tris-HCl. Subsequently, the sections were rinsed in $0.1 \mathrm{M}$ cacodylate buffer, $\mathrm{pH} 7.4$, postfixed in $2.5 \%(\mathrm{v} / \mathrm{v})$ glutaraldehyde in cacodylate buffer $\left(2 \mathrm{hr}\right.$ at $\left.4^{\circ} \mathrm{C}\right)$, and washed in cacodylate buffer overnight at $4^{\circ} \mathrm{C}$. The DAB reaction product was silver-intensified and treated with $0.05 \%(\mathrm{w} / \mathrm{v})$ gold chloride (Sigma), using a modified version of a procedure described previously (Leranth and Pickel, 1989). The sections were then postfixed with $2 \%(\mathrm{w} / \mathrm{v}) \mathrm{OsO}_{4}$ in cacodylate buffer for $1 \mathrm{hr}$, dehydrated in a graded series of ethanol (30-100\%) followed by propyleneoxide, and flat-embedded in Epon 812 (Serva, Heidelberg, Germany). Ultrathin sections were cut and then stained with uranyl acetate and lead citrate. Control vibratome sections were processed as described above, except that the first antibody was omitted. These produced no staining.

Microscopic analysis. For light microscopic analysis, the sections were examined and photographed with a Zeiss photomicroscope (Axiophot, Zeiss, Oberkochen, Germany) using $40 \times, 63 \times$, and $100 \times$ objectives and the appropriate fluorescence filters (FITC: 450-490, FT 510, LP 520; Cy3/Texas Red: BP 546, FT 580, LP 590). The fluorescence filters were wedge-corrected, and shifting from one filter to the other did not cause any displacements of the image. In some instances, very strong Cy3 fluorescence was also visible with the FITC filter. This could be blocked by an additional green interference filter (515-565) inserted into the microscope tube. Black and white photomicrographs were taken on Kodak TMY 400 film, and color micrographs were taken on Kodak Ektachrome EPL 400 color reversal film. Photomicrographs taken from double-labeling experiments were printed as mirror images, cut, and aligned along a common border to show symmetry of immunoreactivity. Ultrathin sections were examined and photographed with a Zeiss EM10 electron microscope.

\section{RESULTS}

\section{Specificity of the anti-mGluR7 antiserum and distribution of mGluR7}

An antiserum was raised against a peptide corresponding to the C-terminal amino acid sequence of mGluR7 and purified by immunoaffinity chromatography. The specificity of the purified antiserum was analyzed by immunoblotting rat retina membranes on SDS-polyacrylamide gels. The immunoblot, developed with the affinity-purified antiserum directed to mGluR7, showed one weakly labeled band of protein (Fig. $1 A$ ). This labeled protein had an apparent molecular weight of $120 \mathrm{kDa}$, in agreement with the deduced molecular weight from the cDNA sequence of mGluR7.

MGluR7 immunoreactivity was present exclusively in cells that stratify within the IPL (Fig. 1B). The stainings revealed two major immunoreactive bands in the outer part (the OFF sublamina) of the IPL. A weakly and more diffusely labeled band could be seen in the inner part (the ON sublamina) of the IPL. Here, mGluR7 staining was restricted to patches of punctate immunoreactivity (Fig. 1E). No mGluR7 staining was detected in the OPL (Fig. 1B).

Preadsorption of the anti-mGluR7 antiserum with the respective antigenic peptide (1:10, for $1 \mathrm{hr}$ at room temperature) before it was applied to sections of rat retina resulted in a complete absence of specific staining (Fig. 1C) compared with the distinct labeling pattern seen with the anti-mGluR7 antiserum alone (Fig. $1 B)$. Figure $1 E$ shows a higher-power view of the punctate labeling pattern for mGluR7 in the IPL. This punctate distribution of the receptor staining at the light microscopic level indicates synaptic 


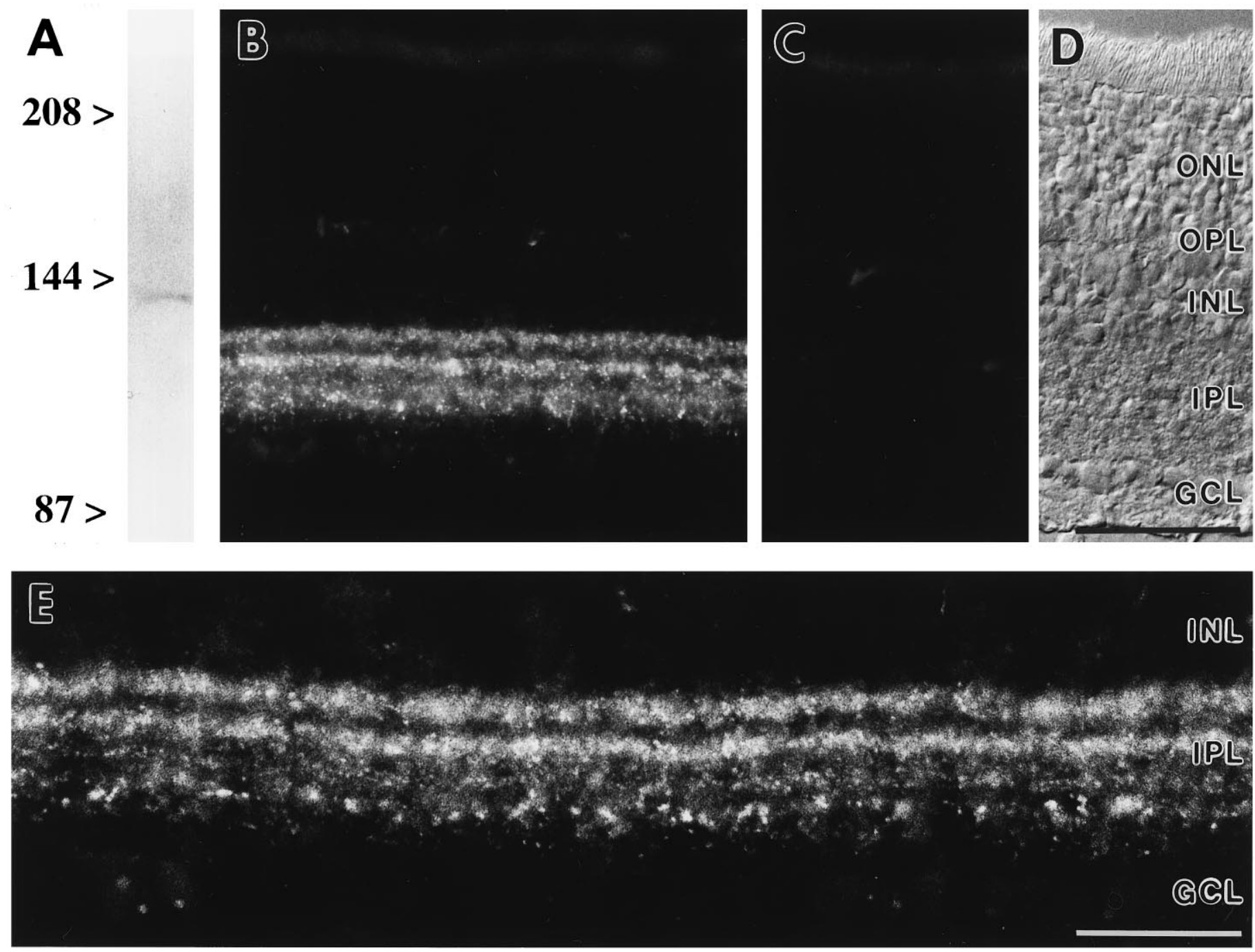

Figure 1. Specificity of the antiserum against mGluR7. A, Western blot of rat retina membrane proteins $(80 \mu \mathrm{g} / \mathrm{lane})$ showed a single band at $\sim 120 \mathrm{kDa}$. $B$, MGluR7 immunoreactivity in vertical cryostat sections of rat retina was confined to the IPL. $C$, Preadsorption of anti-mGluR7 antiserum with the immunogen resulted in complete loss of specific immunoreactivity. $D$, The retinal layers are shown with Nomarski optics. $E$, Higher-power view showing the punctate staining for mGluR7. $O N L$, Outer nuclear layer; $O P L$, outer plexiform layer; $I N L$, inner nuclear layer; $I P L$, inner plexiform layer; $G C L$, ganglion cell layer. Scale bar (shown in $D$ ): $B-D, 50 \mu \mathrm{m} ; E, 25 \mu \mathrm{m}$.

localization (Pourcho and Owczarzak, 1991; Yazulla and Studholme, 1991; Grünert and Wässle, 1993; Hartveit et al., 1994; Sassoe-Pognetto et al., 1994).

We also examined the retinas of mice that had the mGluR7 gene disrupted. Retinas of these mGluR7 knock-out mice showed no specific immunoreactivity for mGluR7 compared with wildtype mice (Fig. 2). Furthermore, the specificity of the reported immunocytochemical data was tested by the omission of the primary antibodies or by the exchange of the secondary antibodies, both resulting in no labeling. The staining in both mice and rat retina showed the same labeling (data for mice not shown).

\section{Subcellular distribution of mGluR7}

We used a very sensitive method combining peroxidase staining with silver intensification and gold toning to examine by electron microscopy the subcellular distribution of mGluR7 (see Materials and Methods). Immunoreactivity was found intracellularly because of the epitope-specificity of the anti-mGluR7 antiserum. MGluR7 was present at synapses, corroborating the light microscopic finding of punctate receptor staining (Fig. 1).

\section{Pre- and postsynaptic localization of mGluR7 at cone bipolar cell ribbon synapses}

MGluR7 was localized presynaptically in the ribbon synapses of some types of OFF- and ON-cone bipolar cells (Fig. 3A,B) but not in rod bipolar cells. MGluR7 was present at the active zone where glutamate is released (Fig. 3A,B). Cone bipolar cell synapses consist of one presynaptic element (the bipolar cell terminal) that releases glutamate onto two postsynaptic elements, one amacrine cell process, and one ganglion cell dendrite or two ganglion cell dendrites (Dowling and Boycott, 1966). The presynaptic terminal contains a synaptic ribbon. Consistently, mGluR7 labeling was not found across the whole extent of the presynaptic active zone, but was preferentially located at only one part of the release site facing one of the two postsynaptic elements (Fig. 3A,B).

In addition to the presynaptic localization of mGluR7, we found the receptor also localized postsynaptic to OFF- and ONcone bipolar cell ribbon synapses with only one of the postsynaptic elements labeled for mGluR7 (Fig. $3 C, D$ ). The majority of the postsynaptic processes stained for mGluR7 belonged to amacrine 

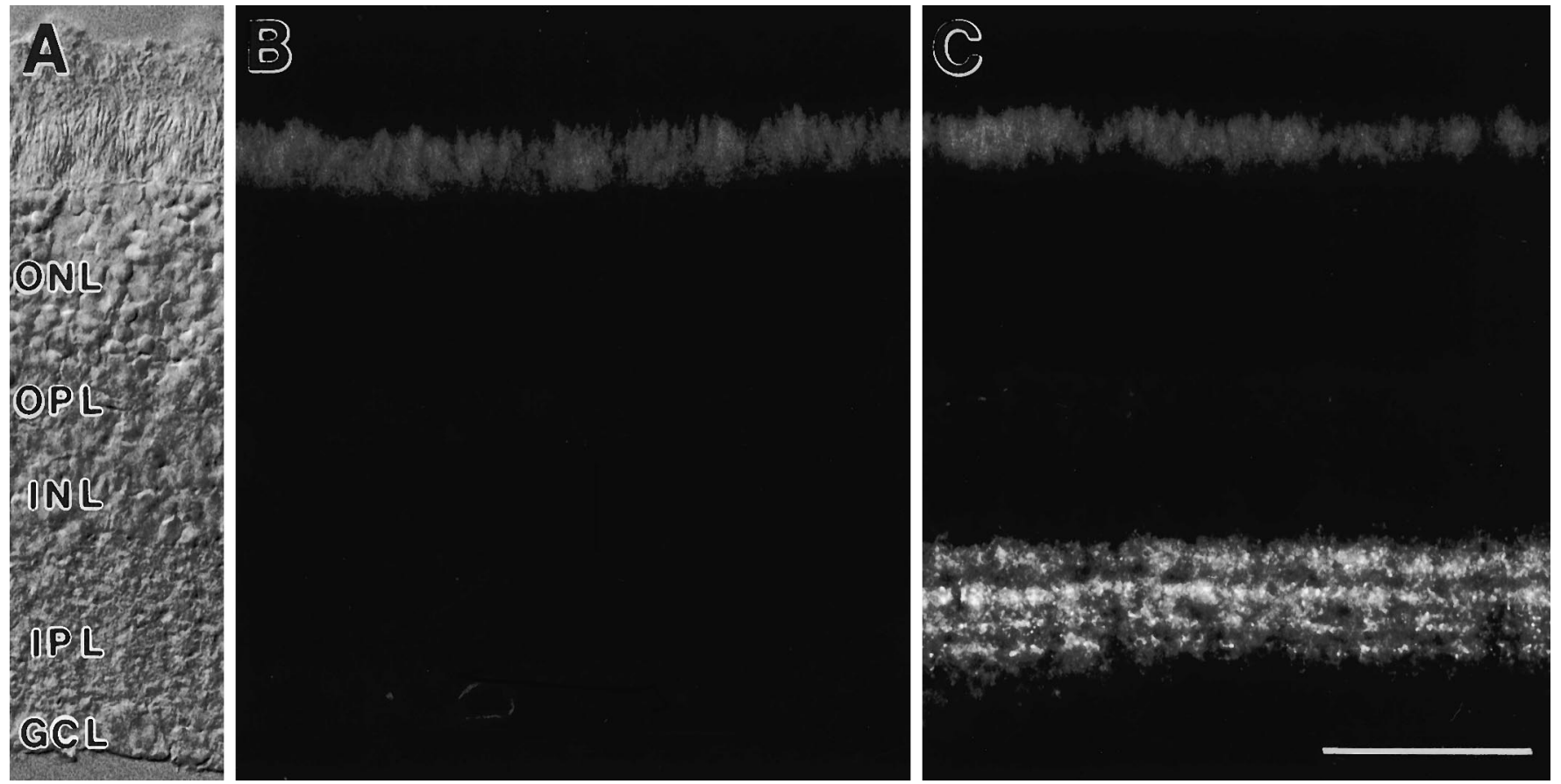

Figure 2. Retina of mGluR7 knock-out mouse. $A$, The retinal layers are shown with Nomarski optics (abbreviations as in Fig. 1). $B$, Absence of specific mGluR7 immunoreactivity in vertical cryostat sections of the retina of mGluR7 knock-out mouse compared with $(C)$ the wild-type staining pattern. Unspecific staining of photoreceptor inner segments can be seen in the outer retina. Scale bar (shown in $C$ ): $50 \mu \mathrm{m}$.

cells (Fig. $3 C, D$ ), but in a very few cases we also found ganglion cell dendrites labeled for mGluR7.

\section{Postnatal development of mGluR7 expression}

During postnatal development, mGluR7 expression was first detected at day 7 (P7). Somata in the inner nuclear layer (INL) and the ganglion cell layer (GCL) and processes in the IPL were immunoreactive (Fig. 4). Between P7 and P10, staining of somata decreased, and a preferential labeling of processes in the IPL could be observed. During this period, the main immunoreactive bands formed in the IPL and reached adult labeling pattern at around P16.

\section{Cell type-specific distribution of mGluR7}

We performed double-labeling experiments to confine mGluR7 staining to defined subsets of retinal neurons. We used the antiserum against mGluR7 in combination with an antibody against choline acetyltransferase (ChAT) (Fig. 5). The antibody against ChAT labels cholinergic amacrine cells and their processes, which stratify in two bands in the IPL (Voigt, 1986). There was no colocalization between mGluR7 and ChAT immunoreactivity, demonstrating that cholinergic amacrine cells do not express mGluR7 (Fig. 5). An antibody against an isoform of protein kinase $\mathrm{C}(\mathrm{PKC} \alpha)$ was shown to label rod bipolar cells and their terminals in the IPL (Greferath et al., 1990). Double-labeling with the antiserum against mGluR7 and the antibody against PKC $\alpha$ also showed no apparent colocalization of mGluR7 with the axon terminals of rod bipolar cells (Fig. 6A,B). An antibody against calbindin (Pinol et al., 1990) also stained, among other cells, a few cone bipolar cells (Fig. 6C,E). Double-labeling with the antiserum against mGluR7 and the antibody against calbindin showed mGluR7 immunoreactive puncta on the axon terminals of these cone bipolar cells (Fig. 6D,F).

\section{DISCUSSION}

\section{MGluR7, a receptor involved in synaptic processing in the IPL of the rat retina}

The absence of mGluR7 immunoreactivity in the OPL of the rat retina indicates that mGluR7 (one of the four known L-AP4sensitive receptors) is not involved in synaptic transmission from the photoreceptors to the bipolar cells. This finding and the fact that another L-AP4-sensitive mGluR, mGluR4, is also not present in the OPL (unpublished data), thus far leaves mGluR6 as the sole mGluR responsible for synaptic transmission from photoreceptor cells to ON bipolar cells (Nakanishi, 1995). The finding that mGluR7 is not expressed by rod bipolar cells but by cone bipolar cells indicates that mGluR7 is involved in photopic and not scotopic vision.

\section{MGluR7, a presynaptic autoreceptor in cone bipolar cells of the rat retina}

Depression of excitatory synaptic transmission is thought to be mediated by group III mGluRs acting as presynaptic autoreceptors (for review, see Pin and Duvoisin, 1995). MGluR7 was localized presynaptically in the ribbon synapses of certain types of OFF- and ON-cone bipolar cells. Furthermore, mGluR7 was present right at the active site where glutamate is released. This is important for the function of the receptor because mGluR7 has the lowest affinity to glutamate or L-AP4 compared with the other group III receptors (for review, see Pin and Duvoisin, 1995). A localization further away from the synapse (perisynaptic) similar to that of mGluR1 $\alpha$ (Baude et al., 1993; Nusser et al., 1994) would create a problem for the activation of mGluR7. Its localization at the site where glutamate is released and its exposure to the highest concentrations of glutamate might explain why mGluR7 has only a relatively low affinity for glutamate.

Most strikingly, mGluR7 labeling was not found across the 

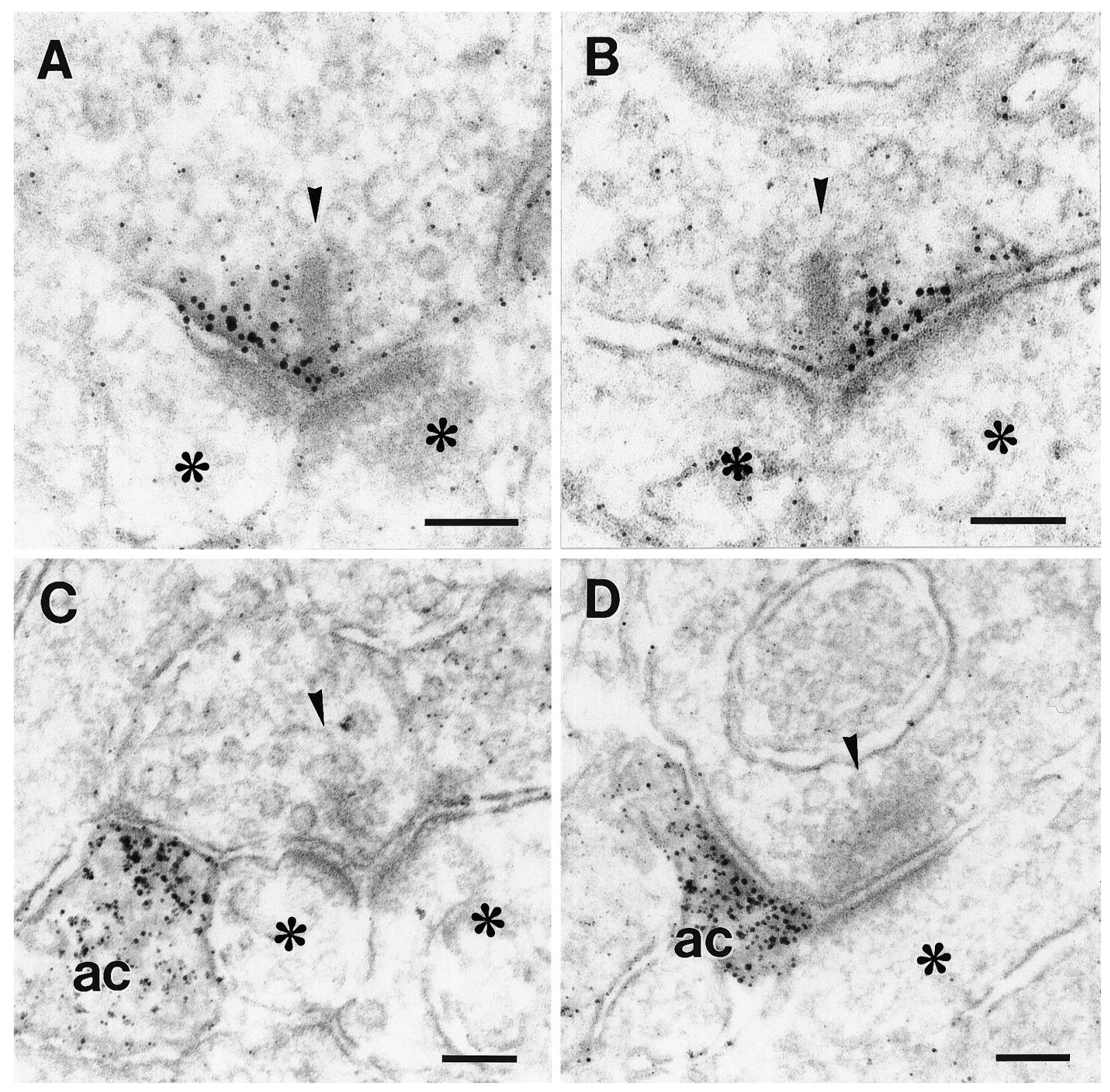

Figure 3. High-power electron micrographs showing the pre- and postsynaptic localization of mGluR7. $A, B$, Presynaptic localization of mGluR7 in an $(A) \mathrm{OFF}$-cone and $(B) \mathrm{ON}$-cone bipolar cell. Note that the receptor-labeling is present along only one part of the active zone, left or right of the presynaptic ribbon. $C, D$, Postsynaptic localization of mGluR7 to an $(C)$ OFF-cone and $(D)$ ON-cone bipolar cell. Note that the receptor-labeling is present in only one of the postsynaptic neurons, the amacrine cell $(a c)$, as identified by the presence of vesicles. Presynaptic ribbons are marked with arrowheads, postsynaptic neurons with asterisks. Scale bars, $0.1 \mu \mathrm{m}$.

whole extent of the presynaptic active zone of the ribbon synapse, but the presynaptic aggregation of mGluR7 was restricted to only one part of the release site facing one of the two postsynaptic elements. We suggest that strategically positioning mGluR7 at only one part of the release site in a retinal ribbon synapse creates a mechanism for differential release of neurotransmitter from the presynaptic site, thus differentially stimulating the postsynaptic cells. The postsynaptic cell facing the part of the release site with mGluR7 would receive, by the action of mGluR7, less glutamate. The other postsynaptic cell, facing the part of the release site without mGluR7, would receive unchanged amounts of glutamate.

Several parameters have been discussed for regulating the strength and kinetics of glutamate synaptic transmission: for ex- ample, the kind of glutamate receptor subtypes used at the postsynaptic site, the density of glutamate receptors at the postsynaptic site, and their relative location to the release site (Baude et al., 1993; Nusser et al., 1994). All of these mechanisms are concerned with receptor heterogeneity at the postsynaptic site. Differential distribution of a receptor like mGluR7 at the presynaptic site creates presynaptic heterogeneity and a mechanism for differential release of neurotransmitter. Such presynaptic specificity may not only play an important role in synaptic transmission at this particular type of synapse in the retina, but could also be of general importance for signal processing at other synapses in the CNS.

Ribbon synapses differ morphologically from conventional synapses by the presence of a so-called ribbon, a band of large surface 

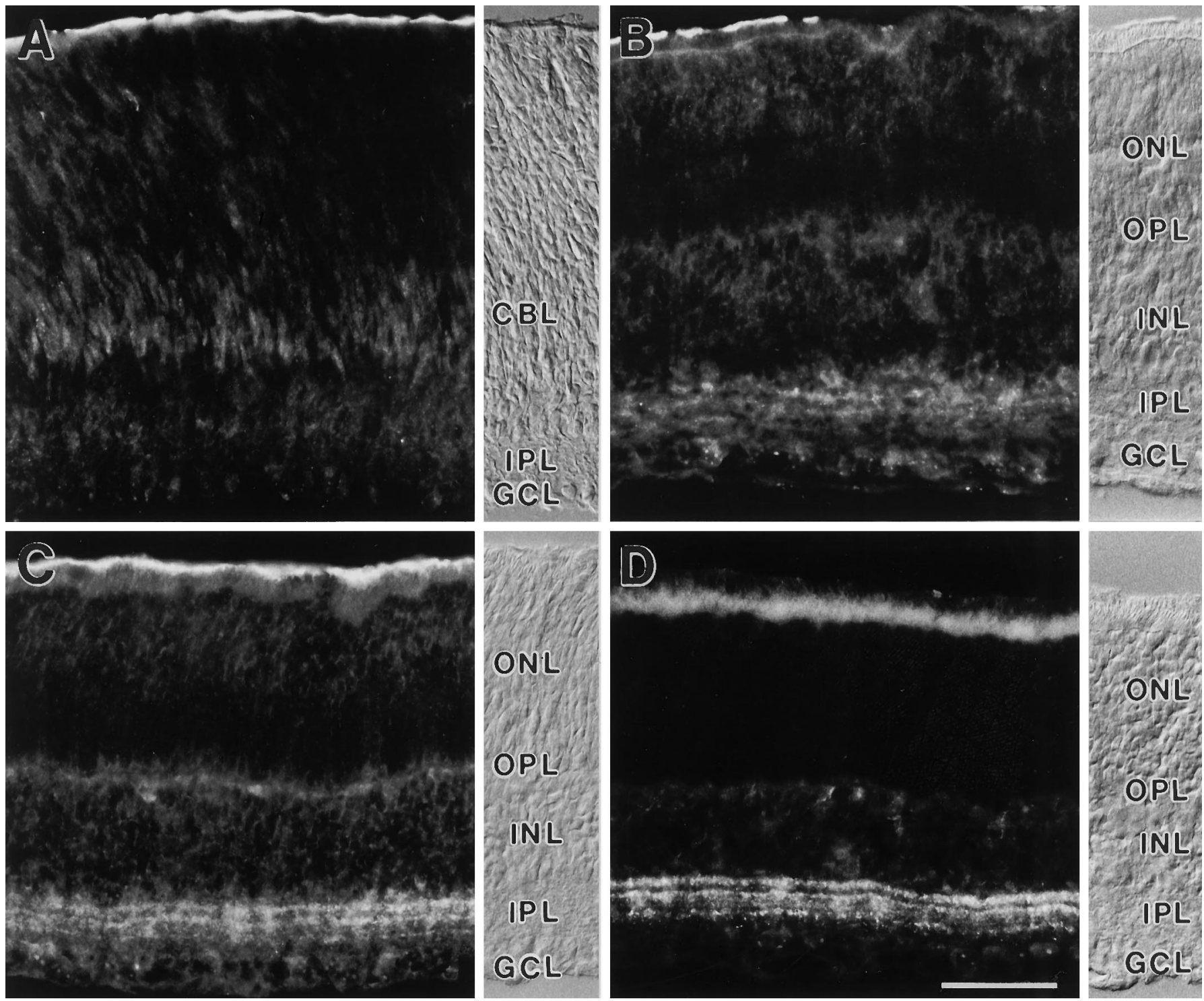

Figure 4. Vertical sections of rat retinas showing the postnatal development of mGluR7 immunoreactivity. The retinal layers are shown with Nomarski optics accompanying each micrograph (abbreviations as in Fig. 1). CBL, Cytoblast layer. A, At postnatal day 5 (P5), no mGluR7-specific staining is found. $B$, A first, diffuse staining of cell somata in the INL and GCL and of processes in the IPL is seen at P7. $C$, Between P7 and P10, staining of somata decreases and preferential labeling of processes in the IPL increases. $D$, MGluR7 expression reaches the adult labeling pattern at around P16. Unspecific staining of photoreceptor inner segments and the pigment epithelium can be seen in the outer retina. Scale bar (shown in $D$ ): $25 \mu \mathrm{m}$.

area adjacent to the presynaptic active zone. Conventional synapses generally have one postsynaptic cell; ribbon synapses have two or more. Although ribbon synapses have been recognized for many years (Sjöstrand, 1958; Dowling and Boycott, 1966), little is known about the function of the ribbon (but see Rao-Mirotznik et al., 1995). We propose that one of the functions of the ribbon could be to compartmentalize the presynaptic site, thus contributing to functional heterogeneity at the synapse. The ribbon could act as a barrier, hindering, for example, the diffusion of free calcium from one part of the release zone to the other. Allbritton at al. (1992) measured the diffusion coefficients for calcium in a cytosolic extract from Xenopus laevis oocytes and showed that calcium acts in restricted domains. They calculated an effective range of free calcium of $0.1 \mu \mathrm{m}$ before it is buffered. This is within the dimension of a ribbon synapse (Dowling and Boycott, 1966).

\section{MGluR7, a receptor localized postsynaptic to cone bipolar cell ribbon synapses in the rat retina}

In addition to the presynaptic localization of mGluR7, we also found the receptor localized postsynaptic to OFF- and ON-cone bipolar cell synapses, with only one of the postsynaptic elements labeled for mGluR7. OFF- and ON-cone bipolar cells have excitatory glutamatergic output onto amacrine and ganglion cells. Amacrine cells are generally inhibitory interneurons releasing either GABA or glycine (for review, see Wässle and Boycott, 1991). Dowling and Boycott (1966) showed that amacrine cells postsynaptic at bipolar cell ribbon synapses in turn make feedback synapses onto the bipolar cell terminals (reciprocal synapses; also see Calkins and Sterling, in press). Binding of glutamate released from the bipolar cell by mGluR7 on the amacrine cell could cause a decrease of transmitter release from the amacrine cell and thus 


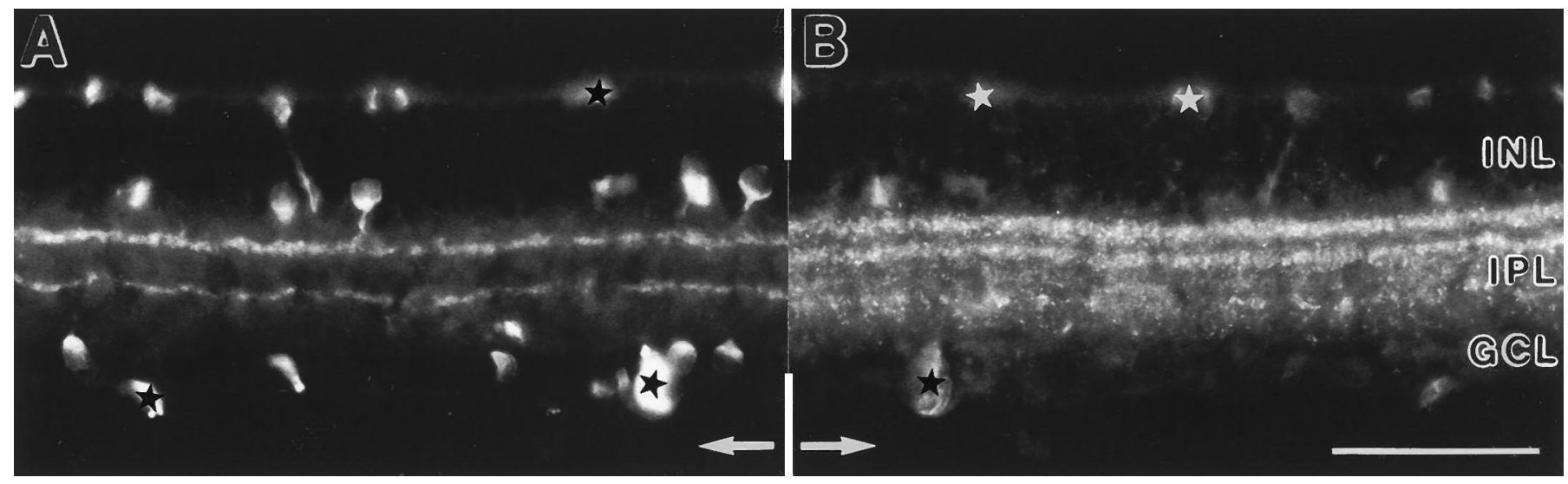

Figure 5. Vertical section of rat retina double-labeled for mGluR7 and ChAT. The two bands of cholinergic amacrine cell processes labeled with an antibody against ChAT $(A)$ are not congruent with the mGluR7-immunoreactive bands in the IPL $(B)$. The micrographs are printed as mirror images and are aligned along a common midline, as indicated by the arrows. Corresponding points therefore are found at equal distances from the midline. Unspecifically stained, larger blood vessels are marked by stars. Abbreviations as in Figure 1. Scale bar, $50 \mu \mathrm{m}$.
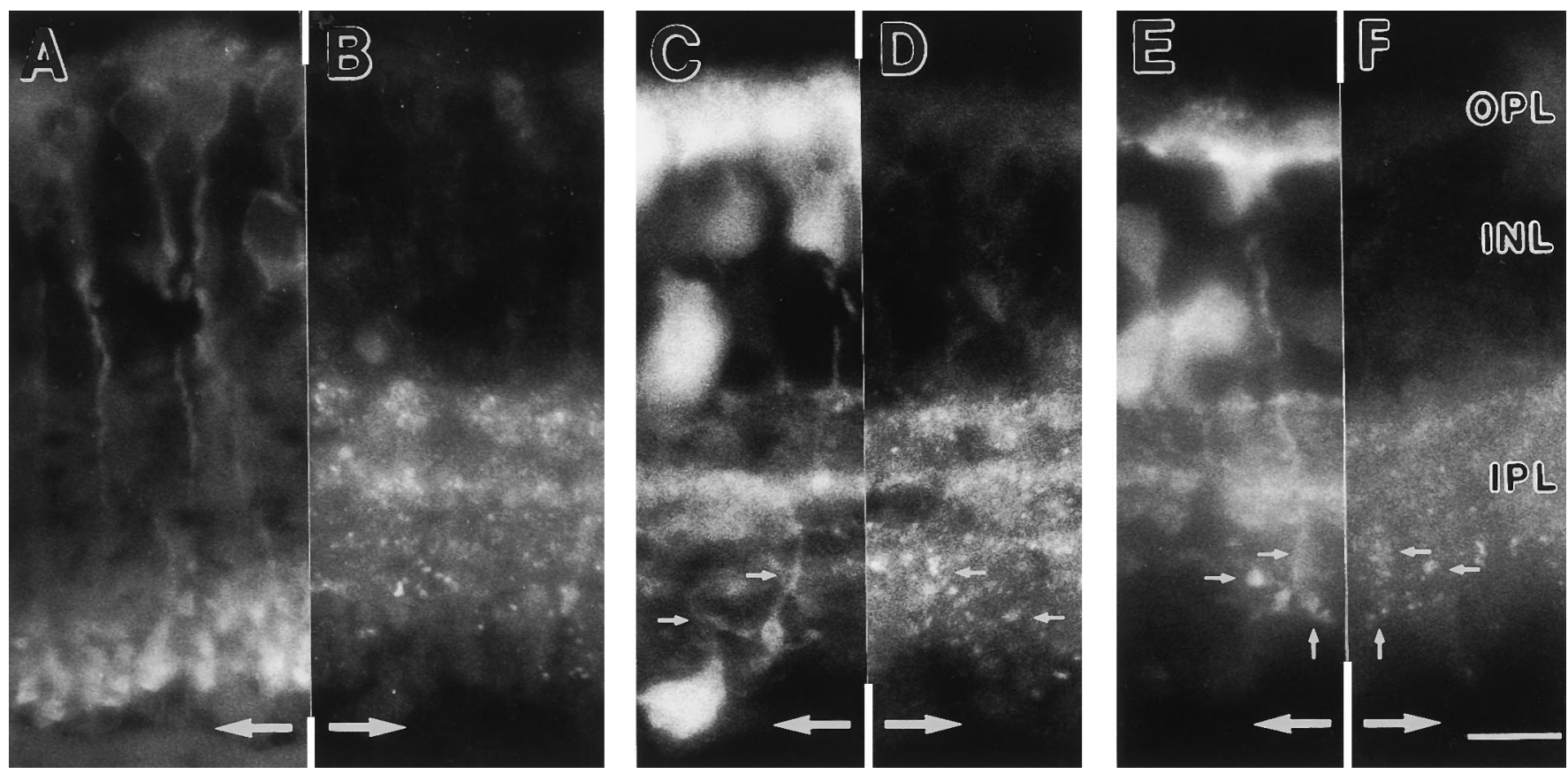

Figure 6. Vertical sections of rat retinas that were double-stained with the antiserum against mGluR7 and antibodies that recognize distinct cell types. The micrographs are printed as mirror images and cut and aligned along a common border. Identical points of the sections therefore are found at equal distances from the midline (large arrows). A, Rod bipolar cells are stained with an antibody against PKC $\alpha$. The lack of symmetry across the midline indicates no colocalization with the mGluR7 staining in $B$. In $C$ and $E$, calbindin-immunopositive bands in the IPL and labeled ON-cone bipolar cells can be seen. Their terminals are colocalized with mGluR7 immunoreactive puncta in $D$ and $F$ (small arrows). Additionally, the outermost calbindinimmunoreactive band $(C, E)$ is congruent with one of the mGluR7-immunoreactive bands $(D, F)$. Abbreviations as in Figure 1. Scale bar (shown in $F$ ): $10 \mu \mathrm{m}$.

a disinhibition of the bipolar cell. A similar mechanism of GABAergic disinhibition was proposed for mitral and granule cell interactions in the olfactory bulb (Hayashi et al., 1993; Nakanishi, 1995).

Binding of glutamate by mGluR7 on the ganglion cell, the second element at the cone bipolar cell synapse, could cause a reversal of the signal and an inhibition of the ganglion cell, as hypothesized for the action of mGluR6 in ON bipolar cells (Nomura et al., 1994; Masu et al., 1995).

\section{MGluR7, a receptor redistributed during development}

MGluR7 was present early in postnatal development at both the somata and processes of neurons. Later in postnatal development, a shift occurred in the expression of mGluR7 solely to localization at processes that stratify in the IPL. This increasing restriction of mGluR7 to the IPL during development resembles the redistribution of mGluR6 from somatic to dendritic localization in the OPL (Nomura et al., 1994). Redistribution of receptor proteins during development might correspond to clustering of receptor proteins and the establishment of functional synapses (Kirsch et al., 1993; Craig et al., 1994).

\section{REFERENCES}

Allbritton NL, Meyer T, Stryer L (1992) Range of messenger action of calcium ion and inositol 1,4,5-triphosphate. Science 258:1812-1815. 
Baude A, Nusser Z, Roberts JDB, Mulvihill E, McIlhinney RAJ, Somogyi $\mathrm{P}$ (1993) The metabotropic glutamate receptor (mGluR1 $\alpha$ ) is concentrated at perisynaptic membrane of neuronal subpopulations as detected by immunogold reaction. Neuron 11:771-787.

Brandstätter JH, Hartveit E, Sassoè-Pognetto M, Wässle H (1994) Expression of NMDA and high-affinity kainate receptor subunit mRNAs in the adult rat retina. Eur J Neurosci 6:1100-1112.

Brecha N (1983) Retinal neurotransmitters: histochemical and biochemical studies. In: Chemical neuroanatomy (Emson PC, ed), pp 85-129. New York: Raven.

Calkins DJ, Sterling P (1996) Absence of spectrally specific lateral inputs to midget ganglion cells in primate retina. Nature, in press.

Craig AM, Blackstone CD, Huganir RL, Banker G (1994) Selective clustering of glutamate and $\gamma$-aminobutyric acid receptors opposite terminals releasing the corresponding neurotransmitter. Proc Natl Acad Sci USA 91:12373-12377.

Dowling JE, Boycott BB (1966) Organization of the primate retina: electron microscopy. Proc R Soc Lond [Biol] 166:80-111.

Duvoisin RM, Zhang C, Ramonell K (1995) A novel metabotropic glutamate receptor expressed in the retina and olfactory bulb. J Neurosci 15:3075-3083.

Greferath U, Grünert U, Wässle H (1990) Rod bipolar cells in the mammalian retina show protein kinase C-like immunoreactivity. J Comp Neurol 301:433-442.

Greferath U, Grünert U, Fritschy JM, Stephenson A, Möhler H, Wässle $\mathrm{H}$ (1995) $\mathrm{GABA}_{\mathrm{A}}$ receptor subunits have differential distributions in the rat retina: in situ hybridization and immunohistochemistry. J Comp Neurol 353:553-571.

Grünert U, Wässle H (1993) Immunocytochemical localization of glycine receptors in the mammalian retina. J Comp Neurol 335:523-537.

Hamassaki-Britto DE, Hermans-Borgmeyer I, Heinemann S, Hughes TE (1993) Expression of glutamate receptor genes in the mammalian retina: the localization of GluR1 through GluR7 mRNAs. J Neurosci 13:1888-1898.

Harlow E, Lane D (1988) Antibodies: a laboratory manual. Cold Spring Harbor, NY: Cold Spring Harbor Laboratory.

Hartveit E, Brandstätter JH, Sassoè-Pognetto M, Laurie DJ, Seeburg PH, Wässle H (1994) Localization and developmental expression of the NMDA receptor subunit NR2A in the mammalian retina. J Comp Neurol 348:570-582.

Hartveit E, Brandstätter JH, Enz R, Wässle H (1995) Expression of the mRNA of seven metabotropic glutamate receptors (mGluR1 to 7) in the rat retina: an in situ hybridization study on tissue sections and isolated cells. Eur J Neurosci 7:1472-1483.

Hayashi Y, Momiyama A, Takahashi T, Ohishi H, Ogawa-Meguro R, Shigemoto R, Mizuno N, Nakanishi S (1993) Role of a metabotropic glutamate receptor in synaptic modulation in the accessory olfactory bulb. Nature 366:687-690.

Hollmann M, Heinemann S (1994) Cloned glutamate receptors. Annu Rev Neurosci 17:31-108.

Keyser KT, Britto LRG, Schoepfer R, Whiting P, Cooper J, Conroy W, Brozozowskaprechtl A, Karten HJ, Lindstrom J (1993) Three subtypes of $\alpha$-bungarotoxin-sensitive nicotinic acetylcholine receptors are expressed in chick retina. J Neurosci 13:442-454.

Kirsch J, Wolters I, Triller A, Betz H (1993) Gephyrin antisense oligonucleotides prevent glycine receptor clustering in spinal neurons. Nature 366:745-748.

Leranth C, Pickel VM (1989) Electron microscopic preembedding double-immunostaining methods. In: Neuroanatomical tract-tracing methods 2. Recent progress (Heimer L, Záborszky L, eds), pp 129-172. New York: Plenum.

Massey CM (1990) Cell types using glutamate as a neurotransmitter in the vertebrate retina. In: Progress in retinal research (Osborne N, Chader J, eds), pp 399-425. Oxford: Pergamon.

Massey CM, Redburn DA (1987) Transmitter circuits in the vertebrate retina. Prog Neurobiol 28:55-96.

Masu M, Iwakabe H, Tagawa Y, Miyoshi T, Yamashita M, Fukuda Y, Sasaki H, Hiroi K, Nakamura Y, Shigemoto R, Takada M, Nakamura K, Nakao K, Katsuki M, Nakanishi S (1995) Specific deficit of the ON response in visual transmission by targeted disruption of the mGluR6 gene. Cell 80:757-765.

Monaghan DT, Bridges RJ, Cotman CW (1989) The excitatory amino acid receptors: their classes, pharmacology, and distinct properties in the function of the central nervous system. Annu Rev Pharmacol Toxicol 29:365-402.

Nakajima Y, Iwakabe H, Akazawa C, Nawa H, Shigemoto R, Mizuno N, Nakanishi S (1993) Molecular characterization of a novel retinal metabotropic glutamate receptor mGluR6 with a high agonist selectivity for L-2-amino-4-phosphonobutyrate. J Biol Chem 268:11868-11873.

Nakanishi S (1994) Metabotropic glutamate receptors: synaptic transmission, modulation, and plasticity. Neuron 13:1031-1037.

Nakanishi S (1995) Second-order neurones and receptor mechanisms in visual- and olfactory-information processing. Trends Neurosci 18:359-364.

Nomura A, Shigemoto R, Nakamura Y, Okamoto N, Mizuno N, Nakanishi S (1994) Developmentally regulated postsynaptic localization of a metabotropic glutamate receptor in rat rod bipolar cells. Cell 77:361-369.

Nusser Z, Mulvihil E, Streit P, Somogyi P (1994) Subsynaptic segregation of metabotropic and ionotropic glutamate receptors as revealed by immunogold localization. Neuroscience 61:421-427.

Okamoto N, Hori S, Akazawa C, Hayashi Y, Shigemoto R, Mizuno N, Nakanishi S (1994) Molecular characterization of a new metabotropic glutamate receptor mGluR7 coupled to inhibitory cyclic AMP signal transduction. J Biol Chem 269:1231-1236.

Peng YW, Blackstone CD, Huganir RL, Yau KW (1995) Distribution of glutamate receptor subtypes in the vertebrate retina. Neuroscience 66:483-497.

Pin JP, Duvoisin R (1995) Neurotransmitter receptors I. The metabotropic glutamate receptors: structure and functions. Neuropharmacology $34: 1-26$.

Pinol MR, Kägi U, Heizmann CW, Vogel B, Séquier JM, Haas W, Hunziker W (1990) Poly- and monoclonal antibodies against recombinant rat brain calbindin D-28K were produced to map its selective distribution in the central nervous system. J Neurochem 54:1827-1833.

Pourcho RG, Owczarzak (1991) Glycine receptor immunoreactivity is localized at amacrine synapses in cat retina. Vis Neurosci 7:611-618.

Rao-Mirotznik R, Harkins AB, Buchsbaum G, Sterling P (1995) Mammalian rod terminal: architecture of a binary synapse. Neuron 14:561-569.

Sassoè-Pognetto M, Wässle H, Grünert U (1994) Glycinergic synapses in the rod pathway of the rat retina: cone bipolar cells express the $\alpha 1$ subunit of the glycine receptor. J Neurosci 14:5131-5146.

Saugstad JA, Kinzie JM, Mulvihill ER, Segerson TP, Westbrook GL (1994) Cloning and expression of a new member of the L-2-amino-4phosphonobutyric acid-sensitive class of metabotropic glutamate receptors. Mol Pharmacol 45:367-372.

Schiller PH (1995) The ON and OFF channels of the mammalian visual system. Prog Ret Eye Res 15:173-195.

Seeburg PH (1993) The molecular biology of mammalian glutamate receptor channels. Trends Neurosci 16:359-365.

Sjöstrand SF (1958) Ultrastructure of retinal rod synapses of the guinea pig eye as revealed by three-dimensional reconstructions from serial sections. J Ultrastruct Res 2:122-170.

Sladeczek F, Pin JP, Récasens M, Bockaert J, Weiss S (1985) Glutamate stimulates inositol phosphate formation in striatal neurones. Nature 317:717-719.

Stief A, Texido G, Sansig G, Eibel H, Le Gros G, van der Putten H (1994) Mice deficient in $\mathrm{CD} 23$ reveal its modulatory role in IgE production but no role in T and B cell development. J Immunol 152:3378-3390.

Sugiyama H, Ito I, Hirono C (1987) A new type of glutamate receptor linked to inositol phospholipid metabolism. Nature 325:531-533.

Tanabe Y, Masu M, Ishii T, Shigemoto R, Nakanishi S (1992) A family of metabotropic glutamate receptors. Neuron 8:169-179.

Tanabe Y, Nomura A, Masu M, Shigemoto R, Mizuno N, Nakanishi S (1993) Signal transduction, pharmacological properties, and expression patterns of two rat metabotropic glutamate receptors, mGluR3 and mGluR4. J Neurosci 13:1372-1378.

Voigt $\mathrm{T}$ (1986) Cholinergic amacrine cells in the rat retina. J Comp Neurol 248:19-35.

Wässle H, Boycott BB (1991) Functional architecture of the mammalian retina. Physiol Rev 71:447-480.

Yazulla S, Studholme KM (1991) Glycine-receptor immunoreactivity in retinal bipolar cells is postsynaptic to glycinergic and GABAergic amacrine cell synapses. J Comp Neurol 310:11-20. 